system over the past decade, there still remain crucial regulations, with a strong concentration on private institutions. These regulations affect every aspect of the operation of private universities, impeding their flexible adjustment in the size and content of education. Small regulations can have a huge impact on the bottom of the hierarchy. Ignoring these repercussions would result in any reform effort of higher education system going nowhere.

\section{Universities Without}

\section{Corruption: A New Approach for Georgia's Higher Education}

\section{Paul Temple}

Paul Temple is lecturer in higher education management at the Institute of Education, University of London. Address: 55-59 Gordon Sq. London SC1H ONTUK. E-mail: p.temple@ioe.ac.uk.

$\mathrm{P}_{\mathrm{d}}^{\mathrm{h}}$ hilip Altbach recently described corruption as "an unprecedented threat to higher education" ("Academic Corruption: The Continuing Challenge," International Higher Education, winter 2005), and recent issues of IHE have presented a range of valuable case studies of higher education corruption. An analysis of corruption in Kyrgyzstan's universities by Madeleine Reeves ("Academic Integrity and Its Limits in Kyrgyzstan," IHE, fall 2004) draws attention to the need to look beyond the university if the causes of corruption, rather than merely its symptoms, are to be confronted. As Georgy Petrov and I have argued in a recent paper on higher education corruption in post-Soviet states (Higher Education Management and Policy, I6(I), 2004), a pervasive lack of trust in formal structures and processes in these countries, which we suggest may be explained in terms of low levels of social capital, means that attempts at anticorruption technical fixes (for example, the grafting on of Western administrative procedures) will fail.

\section{The Republic of Georgia, however, represents a} case of a serious attempt to deal with university corruption as part of a wider attempt at social and economic transformation.

The Republic of Georgia, however, represents a case of a serious attempt to deal with university corruption as part of a wider attempt at social and economic transformation. In November 2003, Georgia's peaceful "rose revolution" began the erosion of post-Soviet authoritarian systems around Russia's borders, which was given further impetus by Ukraine's "orange revolution" a year later. Georgia's new government, led by Mikhail Saakashvili, has the general aim of bringing Georgia "into Europe."

One of the government's objectives is to create a modern, efficient, and, above all, uncorrupt university system. Its main tool in achieving this objective is the 2004 higher education law, supported by a local program known as "universities without corruption." The speed of the law's introduction indicates the priority given by the new government to higher education. This is therefore a crucial moment for Georgia's universities.

\section{The Current Situation}

The universities of Georgia, as creations of the Soviet state, conformed to the standard Soviet pattern. Although the system was characterized by rigid organizational structures, highly didactic academic methods, and an ideological component in many subjects-as well as by close political control—there were undoubtedly academic strengths to be found in many faculties of Georgian universities during the Soviet period.

The years following Georgia's I990 breakaway from the collapsing Soviet Union, until the formation of the Saakashvili government in 2004, were ones of extreme difficulty for the universities. The effects of this period are only too apparent today in badly run-down and poorly equipped buildings, outdated libraries and other facilities, and, most important of all, aging, underpaid and demoralized academic staff.

\section{Georgia's 2004 higher education law provides} the legal framework for change in the public universities.

By 2004 , Georgia was said to have some 300 "universities," a number now reduced to about IIo- this in a country of some five million people. Most of these were new private institutions, established during a time characterized by lack of control and run as money-making businesses. A new national accreditation process is now aimed at bringing some order to this chaotic situation, which threatened to further undermine the country's international academic reputation.

Corruption is reported to have been a major problem in Georgia in the later Soviet period, even when measured against the considerable achievements in this field found elsewhere in the Soviet Union. The problem is generally considered to have become even more acute in Georgia in the period after I990, when ineffective governments themselves became major sites of corruption. Corruption became widespread in the universities, as it did throughout the former Soviet Union, but apparently with few of the corrective mechanisms that-as Georgy Petrov and I found - to some extent limited university corruption in Russia.

\section{Change in the University System}

Georgia's 2004 higher education law provides the legal framework for change in the public universities. An appropriate legal framework is often a necessary part of university reform, 
but it is not on its own a sufficient step: changed attitudes in society, new methods in the universities, and adequate resources are also required.

Many provisions of the new law are aimed directly at the problem of corruption. Thus, a bicameral arrangement for governance has been introduced, with a senate as the overall body responsible for policy and finance and an academic council responsible for academic matters. The greater transparency in decision making as a result of power sharing, which it is hoped this model will provide, is intended as a safeguard against corruption.

This separation of powers includes the creation of the new office of the chancellor (based on the German model), an elective post responsible for administrative and financial matters, accountable to both the senate and the academic council but not to the rector. An organizational distinction has therefore been drawn between the rector's responsibilities for academic matters and the chancellor's responsibilities for the nonacademic - particularly financial-management of the university. This separation of powers is, again, intended to reduce the risk of corruption-though of course it will not assist directly in preventing corruption from occurring in the teacher-student relationship. As many academic decisions produce administrative and financial consequences, this separation of powers builds a permanent tension into the management of the university as a whole; and the law seems to recognize this by setting out a procedure for resolving financial conflicts. I gather that the risks of such conflicts were judged to be worth accepting, if the likelihood of academic decisions being corruptly influenced was thereby reduced.

Another element in making the university's governance and management more transparent is the law's provision for onethird of the senate's members to be students. This appears likely to radically change the nature of university governance in Georgia, particularly if students organize themselves so as vote in a bloc. From the perspective of a university manager, this does raise some practical issues, given an individual student's likely short-term senate membership, as set against the relatively long-term nature of much university decision making.

The law also mandates the establishment in each university of a "quality provision service." This policy may also be seen as a way of introducing transparent academic decision-making processes to make corruption more difficult. The actual content of this "quality" activity is not specified by the law, other than in its references to "systematic evaluation" of teaching and research. One important quality-related point to note is that there is now a general recognition at Georgian universities that the long tradition of the private, individual oral examination is no longer acceptable and must be replaced (or at least supplemented) by written examinations. The creation of such a "paper trail" that can be independently scrutinized is clearly a key anticorruption development.
All Georgian state universities must struggle to survive on inadequate resources. The positive aspect of the situation is that student tuition fees, submitted to honest accounting, now make up about 50 percent-sometimes more-of most universities' income: the Soviet-era tradition of total reliance on state support has disappeared. The future possibility therefore exists for universities to benefit from a buoyant, non-stateincome stream. When students are paying relatively large sums in tuition fees, and have a powerful voice in university governance, it is perhaps possible that an enhanced sense of student "ownership" will further reduce the likelihood of corruption. That was certainly my sense from several recent discussions with student groups.

\section{Corruption, Politics, Society}

Anticorruption measures at Georgian universities seem to have a chance of succeeding because they form part of a wider program of national reforms, driven by a government with a strong, democratic, modernizing mandate. These steps to counter corruption within the universities are not simply technical fixes, unrelated to wider organizational or social change, but form part of a completely new scheme for governance and management in the university. They are also of a piece with more general public-sector reform in the country. Changes to structures and responsibilities in the university are being introduced on foundations laid by more wide-ranging, changed understandings among academics, as exemplified by the recognition that the old oral examination tradition must go. We may consider that corruption is being tackled at Georgian universities through broader attempts at the formation of social capital.

Author's note: My recent work in Georgia was undertaken in conjunction with the Liberty Institute of Georgia, at the request of the British Council Georgia.

\section{New Developments in Colombia's Higher Education}

\section{Consuelo Uribe}

Consuelo Uribe is associate professor and dean of the Faculty of Social Sciences at Javeriana University in Bogota. Address: Facultad de Ciencias Sociales, Edificio Manuel Briceño, zer Piso, Bogota, Colombia. E-mail: curibe@javeriana.edu.co.

ccess to higher education by Colombia's youth population is lagging behind by international and regional standards. 